\title{
Optimising Aged Nanostructured Nickel Oxide Thin Films for Solar Cells Fabrication
}

\author{
Kingsley Ukoba, ${ }^{*}$ Freddie Inambao and Andrew Eloka-Eboka \\ Discipline of Mechanical Engineering, University of Kwazulu-Natal, \\ Mazisi Kunene Road (King George V Avenue), Durban 4041, South Africa \\ ${ }^{*}$ Corresponding Author: ukobaking@yahoo.com
}

Published online: 25 April 2019

To cite this article: Ukoba, K., Inambao, F. \& Eloka-Eboka, A. (2019). Optimising aged nanostructured nickel oxide thin films for solar cells fabrication. J. Phys. Sci., 30(1), 1-15, https://doi.org/10.21315/jps2019.30.1.1

To link to this article: https://doi.org/10.21315/jps2019.30.1.1

\begin{abstract}
The effect of ageing on properties of nickel oxide thin films deposited using spray pyrolysis technique was the focus of this study. Freshly prepared and aged nickel oxide films were successfully deposited by spray pyrolysis technique on a glass substrate at $350^{\circ} \mathrm{C}$. The morphological, elemental, structural and optical properties of two different films were studied. The surface morphology was studied using field emission gun scanning electron microscope. The X-ray diffraction shows that both freshly prepared and aged films have a polycrystalline cubic structure with a preferred orientation along the (llll 11 ) and (2 00$)$ planes. Optical studies show a high transparency in the visible and near infrared regions. The band gap grew with ageing from $3.60 \mathrm{eV}$ to $3.70 \mathrm{eV}$. The optical constant including the refractive index and extinction coefficient reduced with ageing. Based on the result obtained, the prepared sample can be used as the absorber layer of solar cells. The findings may open new frontiers in affordable and efficient solar cell fabrication in developing countries.
\end{abstract}

Keywords: Aged nickel oxide, NiO, spray pyrolysis technique, optical properties, solar cells

\section{INTRODUCTION}

Over $20 \%$ of the world population still struggles with access to electricity, with the majority of those affected being from sub-Sahara Africa and South Asia. ${ }^{1,2}$ The solution to such electricity woes may be found in nanostructured metal oxide. ${ }^{3}$ This is due to the low cost of processing and the simplicity of deposition of metal oxides. Nickel oxide $(\mathrm{NiO})$ holds great promise being a p-type metal oxide with 
a vast range of applications. ${ }^{4-6}$ Several methods have been used to deposit $\mathrm{NiO}$ with a view to optimising it for various applications. The deposition methods are hydrothermal growth, laser ablation, sol-gel, sputtering and atomic layer deposition. ${ }^{7-11}$ However, spray pyrolysis technique (SPT) is preferred for films because it allows coatings on large areas in thin layers with uniform thickness. ${ }^{12}$ SPT's simplicity, affordability and the possibilities for mass production singled it out for this study. ${ }^{13,14}$

The optical properties of a metal oxide play a vital role in its usage in the fabrication of optoelectronic devices. ${ }^{15}$ The optical properties reveal information relating to the microscopic behaviour of the material. Very few works have studied the effect of ageing on $\mathrm{NiO}$ films despite the promise it holds. ${ }^{16}$ The objectives of this study were to prepare and deposit nanostructured $\mathrm{NiO}$ thin films on a glass substrate using SPT, then to determine the effect of ageing on the properties of the $\mathrm{NiO}$ films.

\section{EXPERIMENTAL}

Soda lime glass substrate was chemically and ultrasonically cleaned before used for deposition. The precursor was a mixture of analytical grade nickel acetate tetrahydrate $\mathrm{Ni}\left(\mathrm{CH}_{3} \mathrm{COO}\right)_{2} .4 \mathrm{H}_{2} \mathrm{O}$ of $0.05 \mathrm{M}$ mixed and stirred in $50 \mathrm{ml}$ distilled water. The freshly prepared sample was spray deposited immediately after preparation. The aged sample was left for $192 \mathrm{~h}$ (one week and one day) after mixing to age before deposition. Figure 1 illustrates the schematic set-up used for spray depositing the samples. ${ }^{17}$

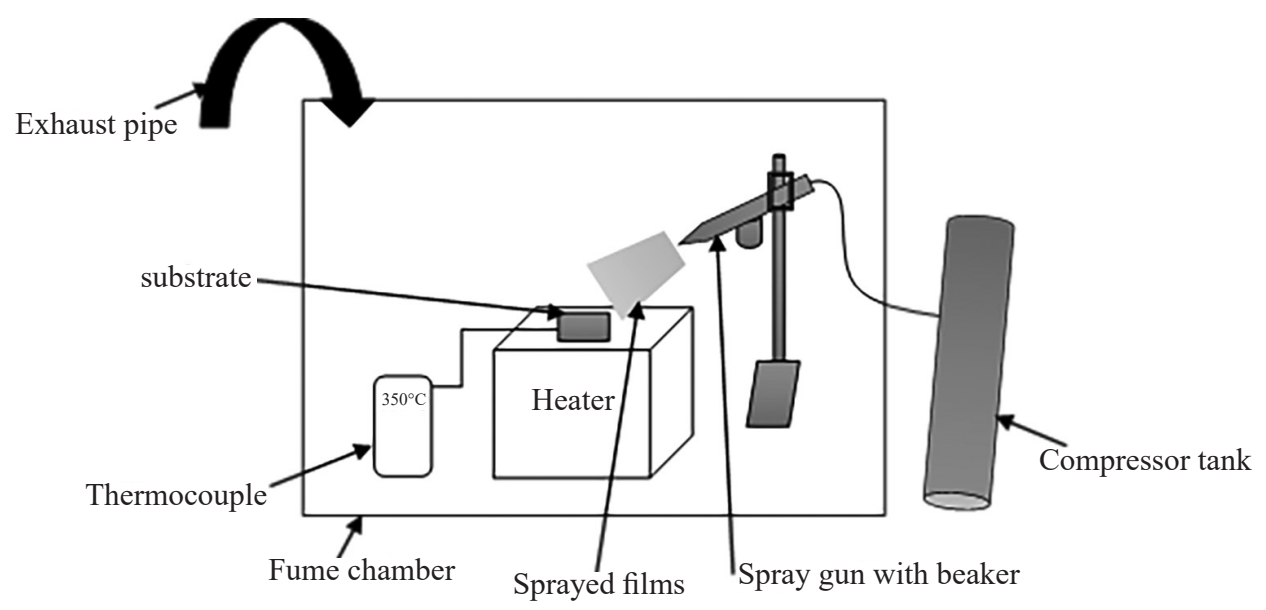

Figure 1: Experimental set-up of spray pyrolysis technique. 
The sprayed solution on the preheated substrate glass undergoes evaporation, solute precipitation and pyrolytic decomposition according to Equation $1 .{ }^{18}$ The end product is a nickel oxide thin film. The pictorial representation of the experimental set up is shown in Figure 2.

$$
\mathrm{Ni}\left(\mathrm{CH}_{3} \mathrm{COO}\right)_{2} \cdot 4 \mathrm{H}_{2} \mathrm{O} \stackrel{\text { heat }}{\longrightarrow} \mathrm{NiO}+7 \mathrm{H}_{2} \mathrm{O} \uparrow+4 \mathrm{CO}_{2} \uparrow
$$

Optimum deposition parameters of the spray deposited NiO films are shown in Table 1. A thermocouple was fixed to the substrate's surface to record substrate temperature.

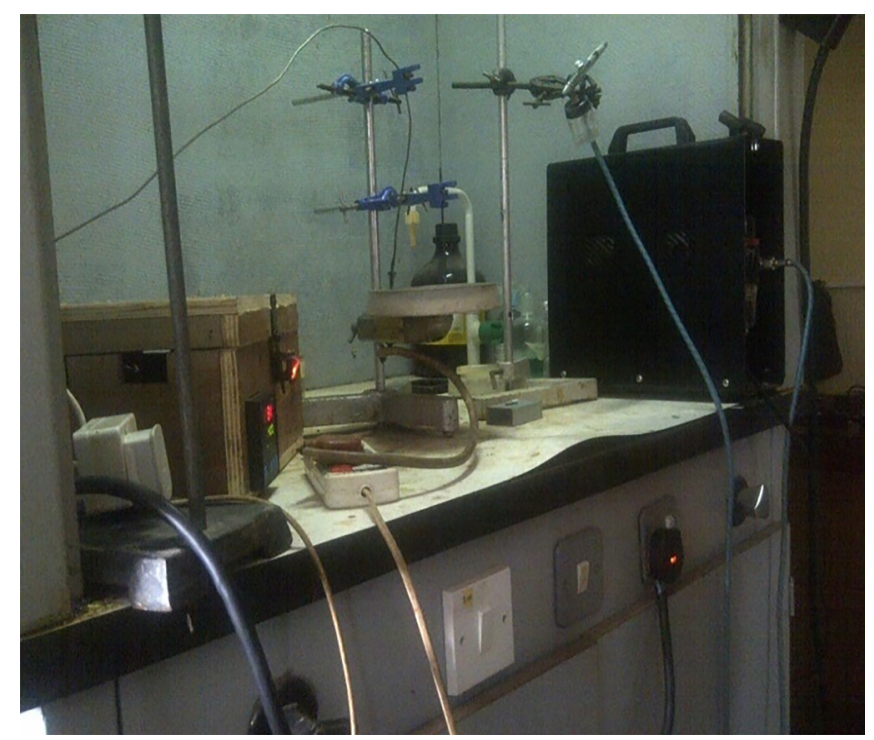

Figure 2: Experimental set-up of the spray pyrolysis.

Table 1: Optimum deposition parameter of SPT NiO films.

\begin{tabular}{ll}
\hline Deposition parameter & Value \\
\hline Substrate temperature & $350^{\circ} \mathrm{C}$ \\
Height of spraying nozzle to substrate distance & $20 \mathrm{~cm}$ \\
Spray rate & $1 \mathrm{ml} \mathrm{min}{ }^{-1}$ \\
Spray time & $1 \mathrm{~min}$ \\
Time between sprays & $30 \mathrm{~s}$ \\
Carrier gas & Filled compressed air of $1 \mathrm{bar}$ \\
\hline
\end{tabular}

The prepared $\mathrm{NiO}$ films were observed to be grey in colour, uniform and strongly adherent to the glass substrate. 


\subsection{Characterisation}

The morphology of deposited $\mathrm{NiO}$ film was studied using a scanning electron microscope (ZEISS EVO MA15VP). An energy dispersive X-ray spectrometer (EDS or EDX: GENESIS XM2) was used for assessing elemental composition. An Empyrean (PANalytical) X-ray powder diffractometer was used for structural properties of deposited $\mathrm{NiO}$ films from $5^{\circ}$ to $90^{\circ} 2 \theta$ angles. The absorption of the film was conducted using a Perkin Elmer spectrum 100 Fourier transform infrared (FTIR) spectrometer. The measured film thickness was compared with the weight difference method. Optical properties were studied in the wavelength range of $300 \mathrm{~nm}$ to $1000 \mathrm{~nm}$ with a Shimadzu UV-3600UV-VIS spectrometer. The results of characterised freshly prepared and aged samples were compared and are reported.

\section{RESULTS AND DISCUSSION}

\subsection{Morphological Studies}

The surface morphologies of the freshly prepared and the aged $\mathrm{NiO}$ films are represented in Figure 3. The freshly prepared micrograph reveals scattered distribution of the tiny particles across the surface of the film. The aged films, however, reveal broader flake-like particles across the surface of the film. Both films have even distribution, are adherent to the film surface, and are devoid of cracks. This may be attributed to proper optimisation of the deposition parameters. This is an improvement on the 24-h aged NiO films reported by Sriram and Thayumanavan. ${ }^{16}$

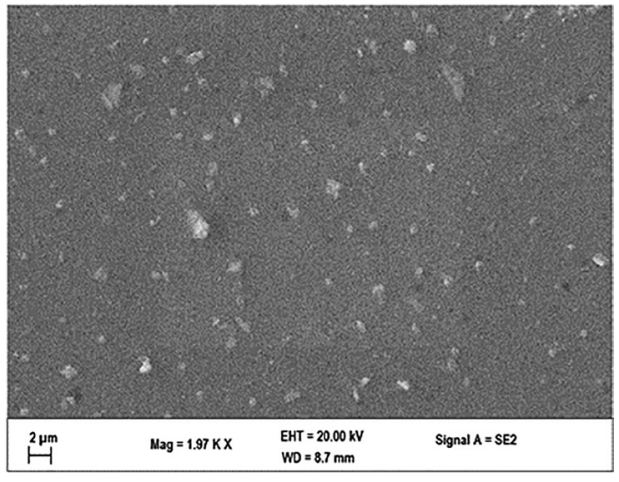

(a)

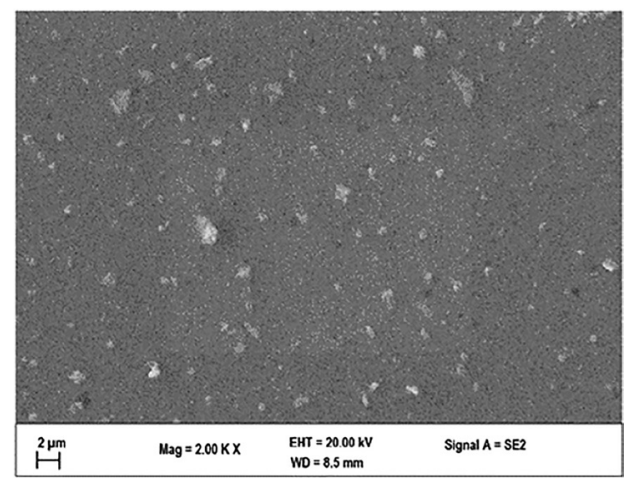

(b)

Figure 3: $\mathrm{SEM}$ micrographs of $\mathrm{NiO}$ film on a glass substrate for (a) freshly prepared, and (b) aged for one week and one day. 


\subsection{Elemental Composition Analysis}

The elemental composition analysis of freshly prepared and aged $\mathrm{NiO}$ thin films are presented in Figures 4(a) and 4(b). Both spectra confirm the presence of Ni and $\mathrm{O}$ elements in the $\mathrm{NiO}$ thin films. Oxygen concentration decreased with ageing. Similarly, nickel weight percent grew for the aged sample in comparison with the freshly prepared film. This may be due to increment in film grown on the glass substrate causing a reduction in the oxygen concentration of the aged films. This observation was also reported by Lu and Hwang. ${ }^{19}$ Apart from the nickel and oxygen, silicon ( $\mathrm{Si}$ ) was also observed. The existence of the $\mathrm{Si}$ is as a result of the elemental composition of the soda-lime glass used as substrate and the EDX of the empty soda-lime glass is shown in the Figure 4(c). ${ }^{20}$

(a)

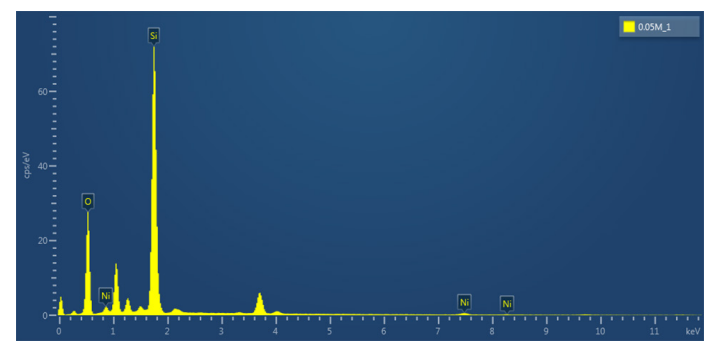

(b)

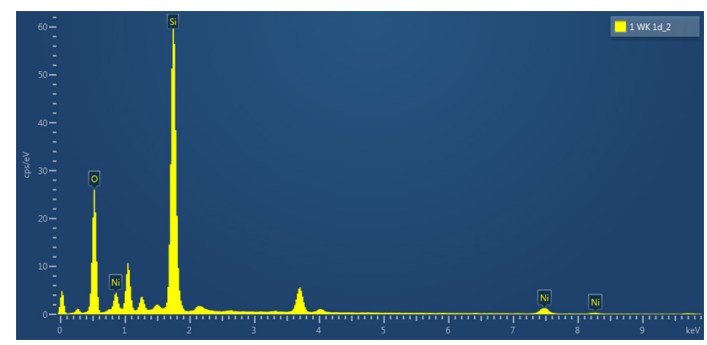

(c)

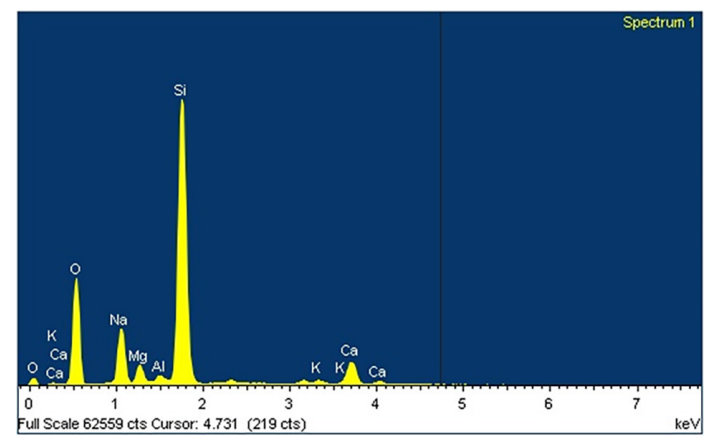

Figure 4: EDX spectra of NiO film on a glass substrate of (a) freshly prepared, (b) aged for one week and one day, and (c) EDX of empty glass. 


\subsection{Structural Studies}

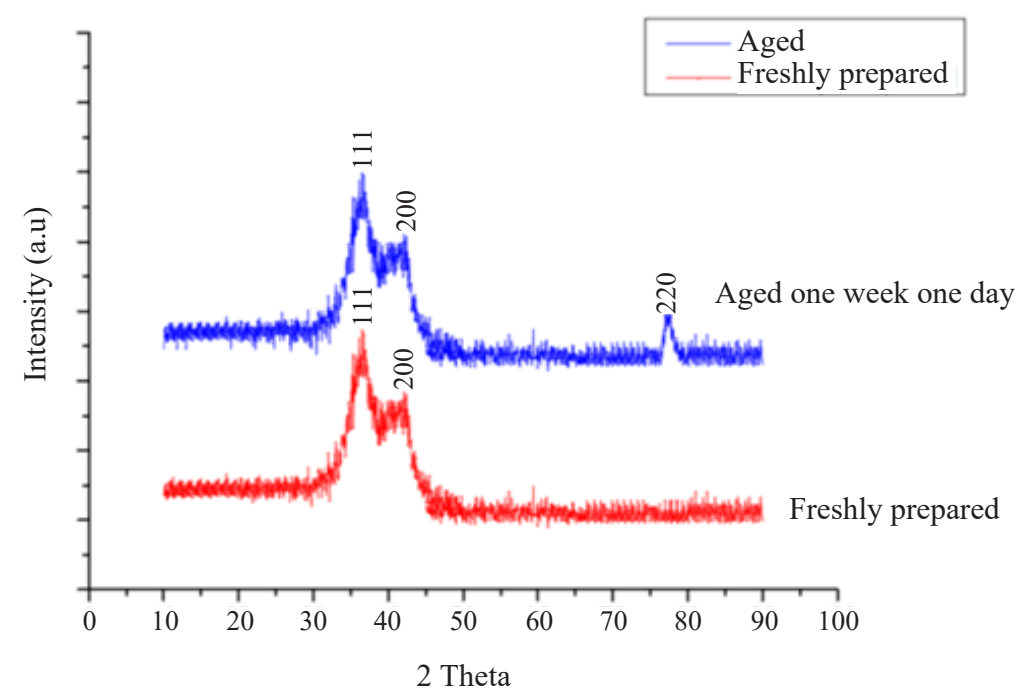

Figure 5: XRD of aged and freshly prepared $\mathrm{NiO}$ films.

The phase present and the preferred orientation of deposited nanostructured $\mathrm{NiO}$ films was determined using an X-ray diffractometer (XRD). The XRD patterns of the aged and freshly deposited films are shown in Figure 5. The films were observed to be polycrystalline with cubic structures. The peaks for the freshly prepared films were observed at $2 \theta$ values of $37^{\circ}$ and $43^{\circ}$ for $\left(\begin{array}{lll}1 & 1 & 1\end{array}\right)$ and $\left(\begin{array}{lll}2 & 0 & 0\end{array}\right)$ planes respectively. However, the aged films were observed at $2 \theta$ values of $36.38^{\circ}$, $43.47^{\circ}$ and $62.01^{\circ}$ for ( $\left.\begin{array}{lll}1 & 1 & 1\end{array}\right),\left(\begin{array}{lll}2 & 0 & 0\end{array}\right)$ and ( 220$)$, respectively. The XRD analysis confirms Bunsenite which corresponds to JCPDS card number 89-7130 for NiO films. The slight difference in the diffraction angle $(2 \theta)$ of the freshly prepared and aged sample may be attributed to the ageing effect of the precursor. The $2 \theta$ for the aged obtained for this study gives an improvement on the earlier reported value of on $2 \theta=36.362^{\circ}, 2 \theta=43.43^{\circ}$ and $2 \theta=62.58^{\circ}$ obtained for 24 -h aged $\mathrm{NiO}$ films earlier reported by Sriram and Thayumanavan. ${ }^{16}$

The films' average particle size was obtained from the Scherrer expression in Equation 2:21,22

$$
D=\frac{k \lambda}{\beta \cos \theta}
$$

where $\beta$ is full width at half maximum (FWHM), $\lambda$ is wavelength, $\theta$ represents Bragg's diffraction angle and $k$ is 0.89 respectively. The values are $22 \mathrm{~nm}$ and $60.4 \mathrm{~nm}$. 


\subsection{NiO Film Absorption (FTIR)}

Figure 6 shows the FTIR spectra used to identify molecular components and the structure of the NiO films. It is done in the range of $400 \mathrm{~cm}^{-1}$ and $4000 \mathrm{~cm}^{-1}$. The $\mathrm{Ni}-\mathrm{O}$ stretching vibration mode was recorded in the broad absorption band region of $432 \mathrm{~cm}^{-1}$ to $698 \mathrm{~cm}^{-1}$. This was also earlier reported as the range of absorption for $\mathrm{NiO}$ films. ${ }^{23}$ The broadness confirms that the $\mathrm{NiO}$ is nanocrystalline. The $\mathrm{NiO}$ film FTIR absorption is blue-shifted due to their nanostructure size. Other significant absorption bands were also recorded. There is no band indicating the presence of other groups. This confirms that there is no impurity in the film and that the sample was washed and well cleaned. This result agrees with standard FTIR data for NiO films as reported by Qiao et al. ${ }^{24}$

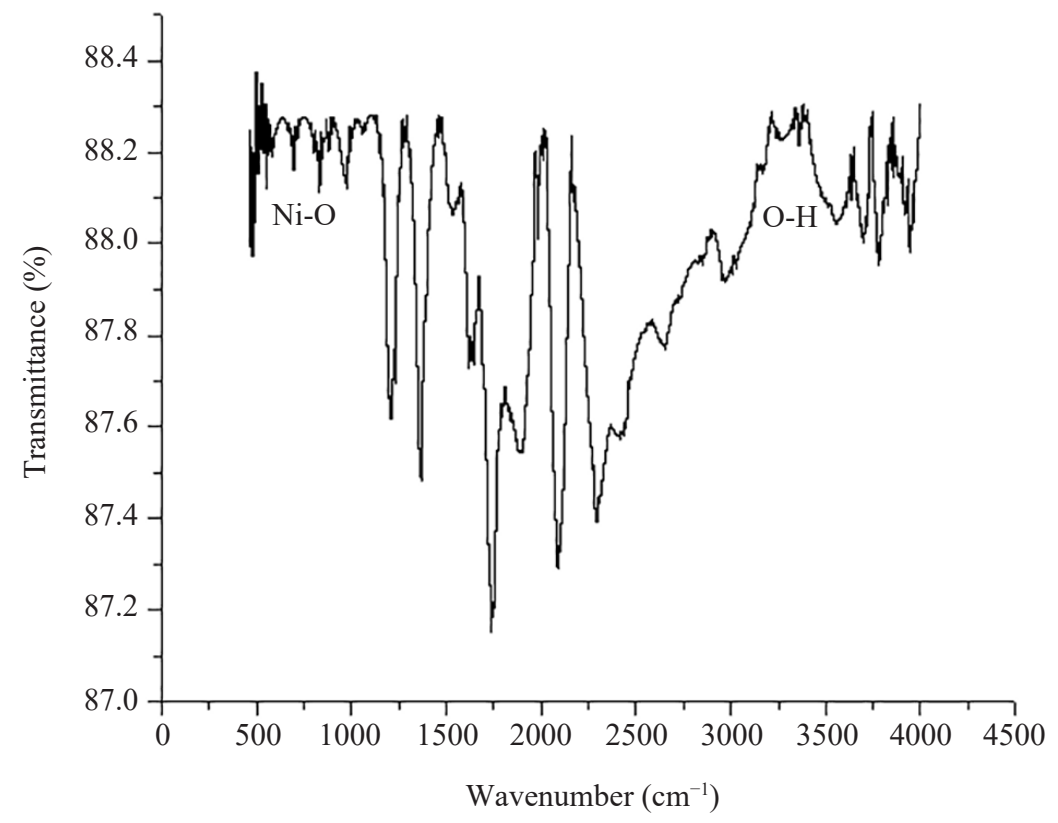

Figure 6: FTIR spectrum of aged and freshly prepared $\mathrm{NiO}$ films.

\subsection{Optical Properties}

\subsubsection{Film thickness}

The film thickness was considered for both freshly prepared and aged films. The film thickness was obtained using SEM cross-sectional profiling as shown in Figure 7. 


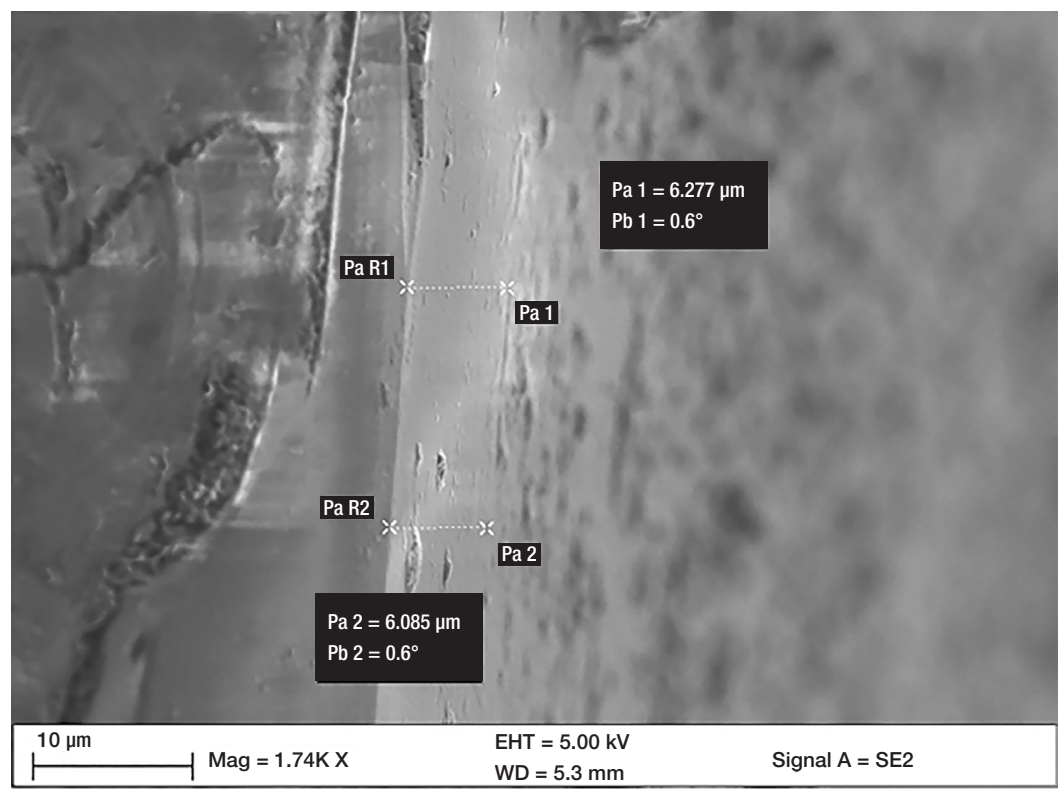

(a)

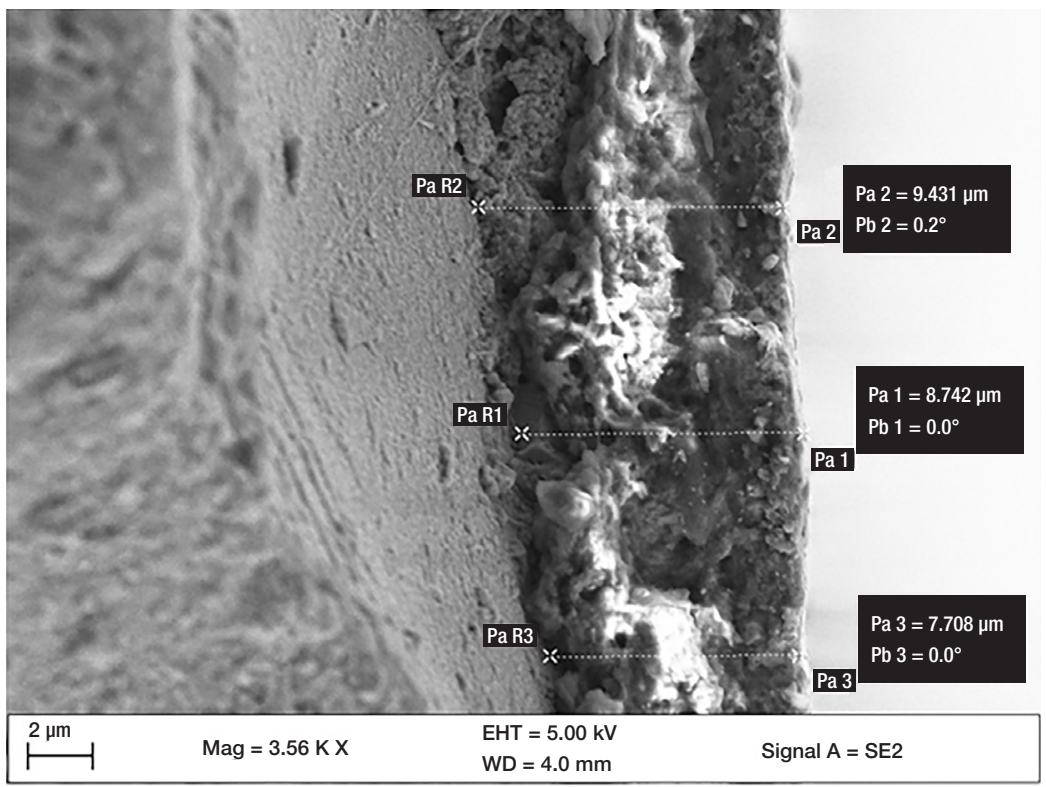

(b)

Figure 7: The film thickness of $\mathrm{NiO}$ film on soda lime glass substrate for (a) freshly prepared, and (b) aged for one week and one day using SEM. 
Figure 8 gives the results for the film thickness computed using the weight difference method expressed in Equation $3: 25$

$$
t=\frac{m}{A \rho}
$$

where $t$ denotes film thickness, $m$ represents the actual mass deposited, $A$ denotes thin film area, while $\rho$ represents the density of the material. The film thickness grew with ageing. The thickness of the films was controlled by keeping deposition parameters constant. The $\mathrm{NiO}$ thin films average thickness was between $6.277 \mu \mathrm{m}$ and $8.627 \mu \mathrm{m}$ for freshly prepared and aged respectively.

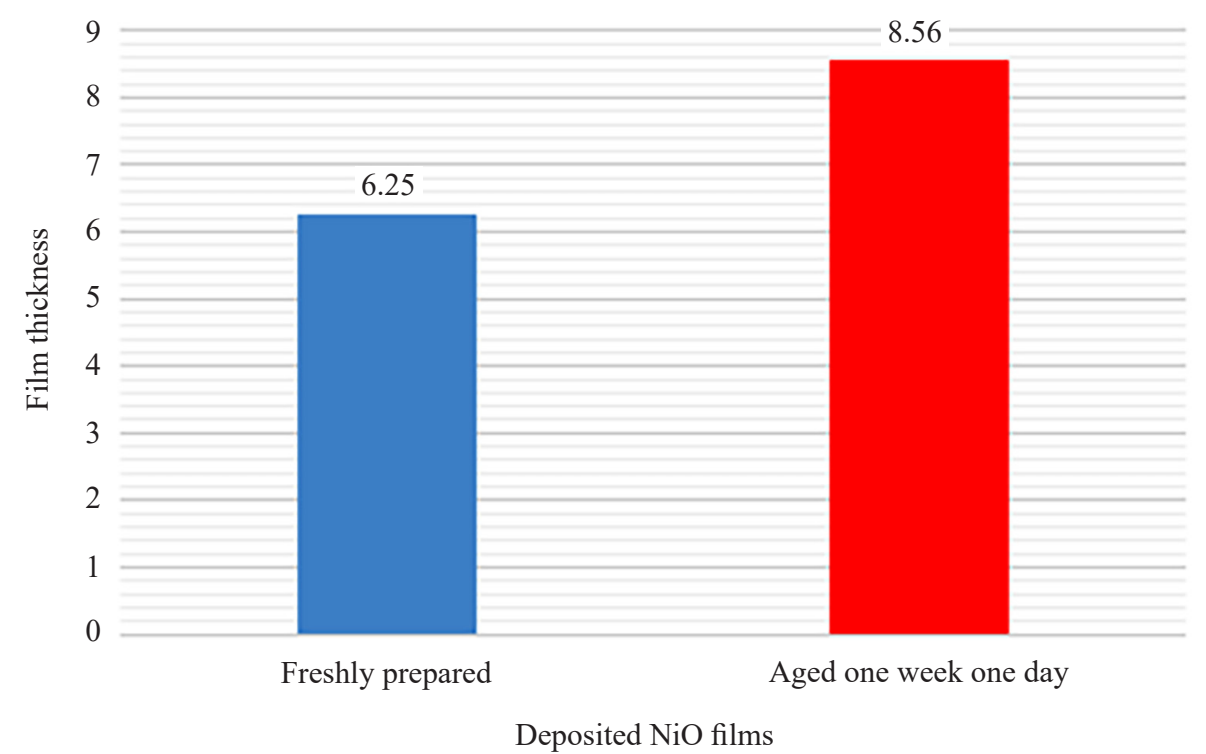

Figure 8: The calculated film thickness of freshly prepared and aged $\mathrm{NiO}$ films.

There is no marked difference between both values from the SEM profiling and the weight difference computed result.

\subsubsection{Transmittance}

The transmission spectra of the freshly prepared and aged $\mathrm{NiO}$ films are shown in Figure 9. The absorption edge occurred for both samples at $360 \mathrm{~nm}$ which compares favourably with $350 \mathrm{~nm}$ obtained by Sriram and Thayumanavan. ${ }^{16}$ The aged film has more transparency than the freshly prepared films occurring at approximately $83 \%$ and $78 \%$, respectively. The aged films showed high transparency in both visible and near-infrared (NIR) regions. 


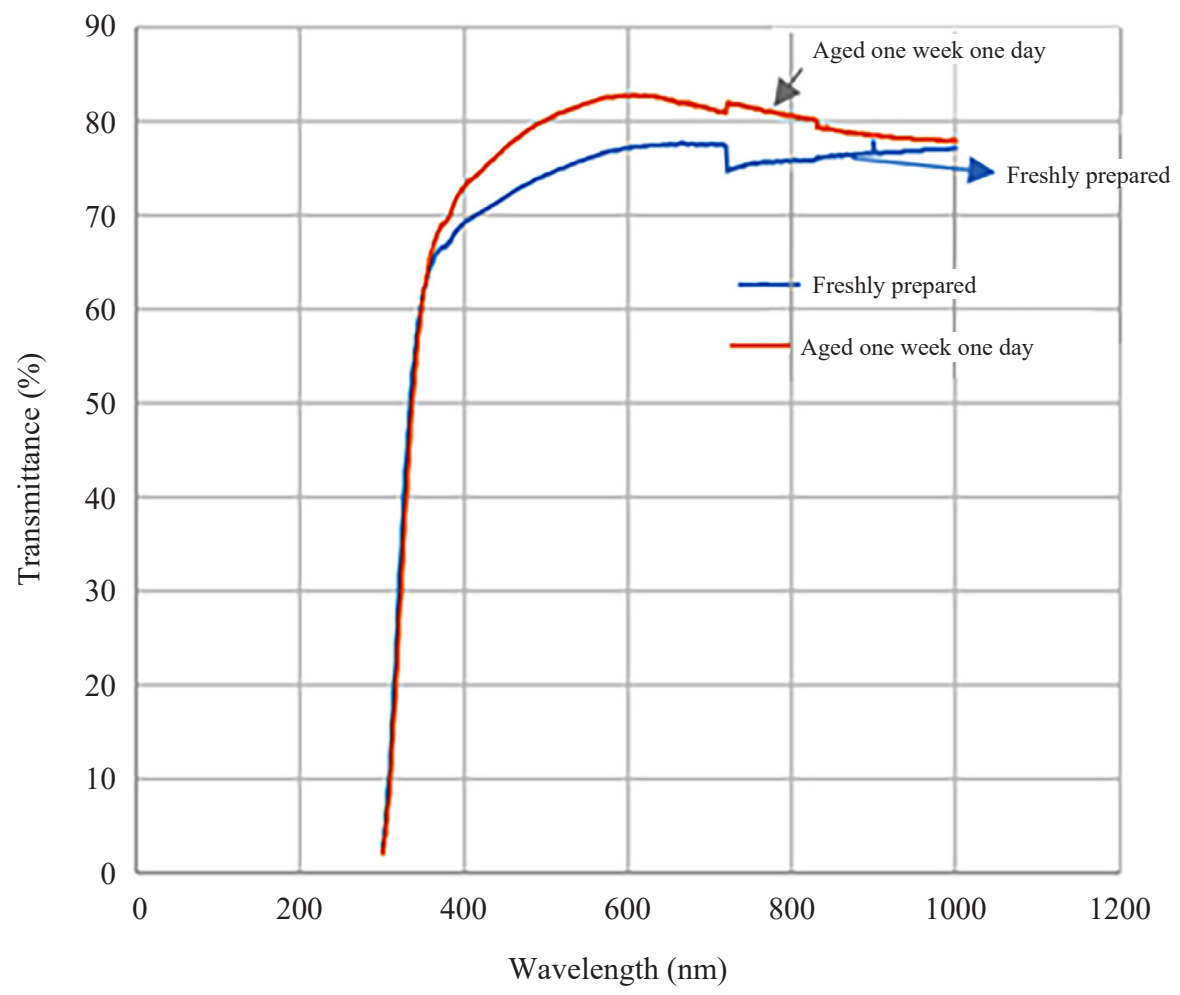

Figure 9: Transmission spectra of freshly prepared and aged $\mathrm{NiO}$ films.

\subsubsection{Optical band gap}

Figure 10 shows a graph of $(\alpha h v)^{2}$ against hv for aged and freshly prepared spray deposited $\mathrm{NiO}$ films. The optical band gap is obtained from extrapolation of Figure 10 to the hv axis when $(\alpha h v)^{2}=0$. The optical band gap grew with the aged $\mathrm{NiO}$ films. A shift towards lower energy was observed for the value of the optical band gap. This may be attributed to the Moss-Burstein shift. ${ }^{26,27}$ The recorded optical energy band gaps are $3.60 \mathrm{eV}$ for freshly prepared and $3.70 \mathrm{eV}$ for aged $\mathrm{NiO}$ films. This gives a better optical band gap compared to the existing reported value of $3.50 \mathrm{eV}$ by Boschloo and Hagfeldt. ${ }^{28}$ This may be ascribed to crystallite size increment. ${ }^{29}$ Quantum size effect may be responsible for the large value of the band gap of $\mathrm{NiO}$ films. ${ }^{30}$ Careful and well-optimised deposition parameters also helped in obtaining better optical band gap values. 


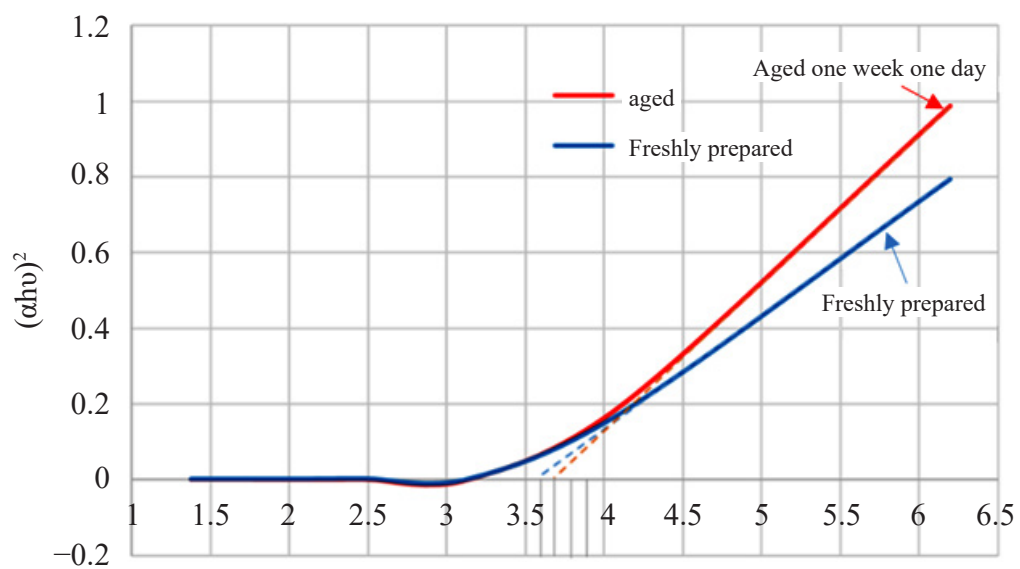

(hv)

Figure 10: Graph of $(\alpha h v)^{2}$ against hv of freshly prepared and aged NiO films.

\subsubsection{Optical constant}

The optical constant can be termed as the "fingerprint of an optical material." The optical constant alongside the thickness of the film is useful for allowing repeatable manufacturing. Refractive index and extinction coefficients are jointly termed optical constants. They are actually not a constant because their values are influenced by photon energy. They both describe how photons of different energies interact with the films. ${ }^{31}$ The interface between a film and the incident ray which is associated with refraction and absorption gives the refractive index $(\eta)$ and the extinction coefficient $(\mathrm{k})$, respectively. ${ }^{32}$

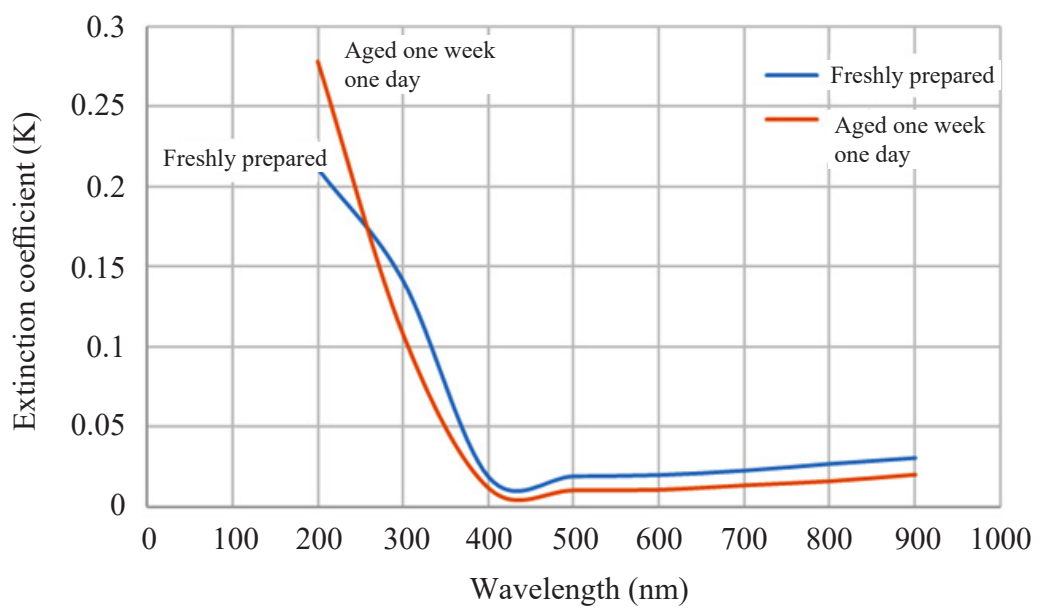

Figure 11: The extinction coefficient of freshly prepared and aged $\mathrm{NiO}$ films. 
The films extinction coefficients were computed over the visible and near-infrared wavelength from the absorption coefficient using Equation 4 by Lee and Lai: ${ }^{33}$

$$
k=\frac{\alpha \lambda}{4 \pi}
$$

where $k$ denotes the extinction coefficient, $\alpha$ represents the absorption coefficient, while $\lambda$ is wavelength. Figure 11 gives the extinction coefficient for the freshly prepared and aged $\mathrm{NiO}$ films. It shows that the extinction coefficients of both films vary within the UV region and are almost constant for both visible and NIR regions.

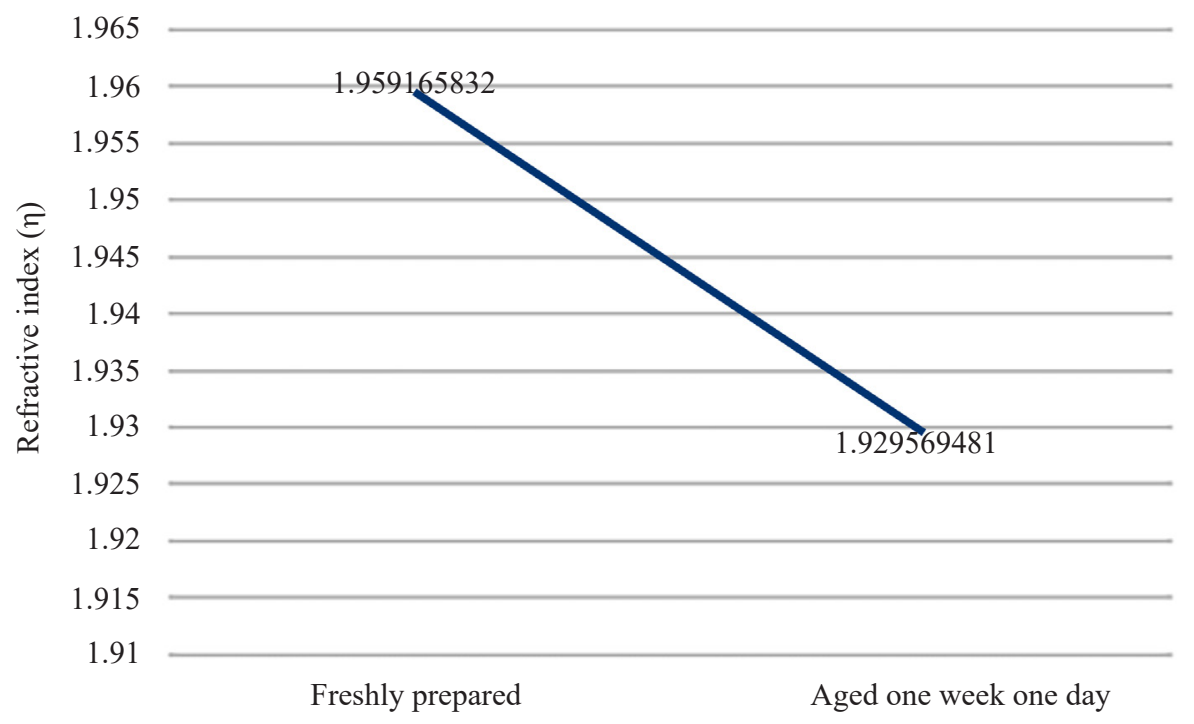

Figure 12: Refractive index of freshly prepared and aged NiO films.

Figure 12 shows the refractive index of both samples. Refractive index is a major property of an optical material which gives the electronic polarisation of ions and the local field inside the material. ${ }^{34}$ The refractive index of deposited films was calculated using the refractive index and optical band gap expression is shown in Equation 5 by Reddy et al: ${ }^{35}$

$$
\eta=\sqrt{(12.417 /(\operatorname{Eg}-0.365))}
$$

where $\eta$ denotes refractive index while $E_{g}$ represents optical band gap. The refractive indices were found to be 1.9592 and 1.9295 for freshly prepared and aged, respectively. This is an improvement on reported values of 1.95 and 1.99 by Sriram and Thayumanavan. ${ }^{16}$ 


\section{CONCLUSION}

This study was able to advance research on $\mathrm{NiO}$ films for solar cells fabrication by spray depositing freshly and $192 \mathrm{~h}$ aged $\mathrm{NiO}$ films. The surface morphology of the deposited $\mathrm{NiO}$ films showed broader flakes with ageing. Nickel weight percent grew for the aged sample in comparison with the freshly prepared film. Film thickness grew with ageing. An improved absorption edge was recorded for both freshly prepared and $192 \mathrm{~h}$ aged $\mathrm{NiO}$ films at $360 \mathrm{~nm}$. The aged film had more transparency than the freshly prepared films, with the aged film having approximately $83 \%$ and freshly prepared $78 \%$ transparency. An improved value for optical band gaps for $\mathrm{NiO}$ films was recorded at $3.60 \mathrm{eV}$ and $3.70 \mathrm{eV}$ for freshly prepared and aged $\mathrm{NiO}$ films, respectively. The "fingerprint of an optical material" for $\mathrm{NiO}$ films was reduced for the aged film. The extinction coefficients of both films varied within the UV region and were almost constant for both visible and near-infrared regions. The refractive indices were found to be 1.9592 and 1.9295 for freshly prepared and aged films, respectively. Based on the result obtained, the prepared sample can be used as the absorber layer of a solar cell. These improved results were as a result of careful and well-optimised deposition parameters.

\section{ACKNOWLEDGEMENTS}

The authors acknowledge the National Research Foundation and the World Academy of Science (NRF-TWAS) grant for this research with reference number 105492 .

\section{REFERENCES}

1. Shyu, C. W. (2014). Ensuring access to electricity and minimum basic electricity needs as a goal for the post-MDG development agenda after 2015. Energy Sustain. Dev., 19, 29-38, https://doi.org/10.1016/j.esd.2013.11.005.

2. Adib, R. (2015). Renewables global status report. Paris: REN21.

3. Serrano, E., Garcia-Martinez, J. \& Rus, G. (2009). Nanotechnology for sustainable energy. Renew. Sustain. Energy Rev., 13, 2373-2384, https://doi.org/10.1016/j. rser.2009.06.003.

4. Nam, W. J. et al. (2015). ALD NiO Thin films as a hole transport-electron blocking layer material for photo-detector and solar cell devices. ECS Trans., 66, 275-279, https://doi.org/10.1149/06601.0275ecst.

5. Wu, C. C. \& Yang, C. F. (2015). Effect of annealing temperature on the characteristics of the modified spray deposited Li-doped $\mathrm{NiO}$ films and their applications in transparent heterojunction diode. Sol. Energy Mater. Sol. Cells, 132, 492-498, https://doi.org/10.1016/j.solmat.2014.09.017. 
6. Zhu, Z. et al. (2014). High-performance hole extraction layer of sol-gel-processed $\mathrm{NiO}$ nanocrystals for inverted planar perovskite solar cells. Ang. Chem., 126, 12779-12783, https://doi.org/10.1002/ange.201405176.

7. Kerli, S. \& Alver, Ü. (2016). Preparation and characterisation of $\mathrm{ZnO} / \mathrm{NiO}$ nanocomposite particles for solar cell applications. J. Nanotechnol., Article ID 4028062, https://doi.org/10.1155/2016/4028062.

8. Sasi, B. \& Gopchandran, K. G. (2007). Preparation and characterization of nanostructured $\mathrm{NiO}$ thin films by reactive-pulsed laser ablation technique. Sol. Energy Mater. Sol. Cells, 91, 1505-1509, https://doi.org/10.1016/j.solmat.2007. 04.019 .

9. Kim, K. H. et al. (2014). Effects of $\mathrm{Cu}$ doping on nickel oxide thin film prepared by sol-gel solution process. Opt. Int. J. Light Electr. Optics, 125, 2899-2901, https://doi.org/10.1016/j.ijleo.2013.11.074.

10. Wang, K. C. et al. (2014). Low temperature sputtered nickel oxide compact thin film as effective electron blocking layer for mesoscopic $\mathrm{NiO} / \mathrm{CH} 3 \mathrm{NH} 3 \mathrm{PbI} 3$ perovskite heterojunction solar cells. ACS Appl. Mater. Interf., 6, 11851-11858, https://doi.org/10.1021/am503610u.

11. Hsu, C. C. et al. (2015). Atomic layer deposition of NiO hole-transporting layers for polymer solar cells. Nanotechnol., 26(38), 385201, https://doi.org/10.1088/09574484/26/38/385201.

12. Gowthami, V. et al. (2014). Structural and optical studies on nickel oxide thin film prepared by nebulizer spray technique. Phys. B Condens. Matter., 452, 1-6, https://doi.org/10.1016/j.physb.2014.06.030.

13. Patil, P. S. (1999). Versatility of chemical spray pyrolysis technique. Mater. Chem. Phys., 59,185-198, https://doi.org/10.1016/S0254-0584(99)00049-8.

14. Faraj, M. G. (2015). Effect of aqueous solution molarity on the structural and electrical properties of spray pyrolysed lead sulfide $(\mathrm{PbS})$ thin films. Int. Lett. Chem. Phys. Astron., 57, 122-125, https://doi.org/10.18052/www.scipress.com/ ILCPA.57.122.

15. Gowthami, V. et al. (2014). Optical dispersion characterization of $\mathrm{NiO}$ thin films prepared by nebulized spray technique. Int. J. ChemTech Res., 6, 5196-5202.

16. Sriram, S. \& Thayumanavan, A. (2013). Structural, optical and electrical properties of $\mathrm{NiO}$ thin films prepared by low cost spray pyrolysis technique. Int. J. Mater. Sci. Eng., 1, 118-121.

17. Ukoba, K. O., Eloka-Eboka, A. C. \& Inambao, F. L.(2017). Review of nanostructured $\mathrm{NiO}$ thin film deposition using the spray pyrolysis technique. Renew. Sustain. Energy Rev., 82, 2900-2915, https://doi.org/10.1016/j.rser.2017.10.041.

18. De Jesus, J. C. C. et al. (2005). Thermal decomposition of nickel acetate tetrahydrate: An integrated study by TGA, QMS and XPS techniques. J. Mol. Catal. A Chem., 228, 283-291, https://doi.org/10.1016/j.molcata.2004.09.065.

19. Lu, Y., Hwang, W. S. \& Yang, J. (2002). Effects of substrate temperature on the resistivity of non-stoichiometric sputtered NiO x films. Surf. Coat. Technol., 155, 231-235, https://doi.org/10.1016/S0257-8972(02)00037-3.

20. De Jong, B. H. W. S. (1989). Glass in Ulmann's encyclopedia of industrial chemistry, 5th ed. Weinheim: VCH publishers. 
21. Scherrer, P. (1918). Bestimmung der Grösse und der inneren struktur von: Kolloidteilchen mittels Röntgenstrahlen. Nachr. Ges. Wiss. Göttingen, 26, 98-100.

22. Das, M. R. \& Mitra, P. (2017). Microstructural, optical and ethanol sensing characteristics of CBD-synthesised $\mathrm{AgO}$ thin film: Influence of bath temperature. J. Phys. Sci., 28(2), 127-141, https://doi.org/10.21315/jps2017.28.2.9.

23. Anandan, K. \& Rajendran, V. (2011). Morphological and size effects of NiO nanoparticles via solvothermal process and their optical properties. Mater. Sci. Semicon. Proc., 14, 43-47, https://doi.org/10.1016/j.mssp.2011.01.001.

24. Qiao, H. et al. (2009). Preparation and characterization of $\mathrm{NiO}$ nanoparticles by anodic arc plasma method. J. Nanomater., Article ID 795928, https://doi. org $/ 10.1155 / 2009 / 795928$.

25. Godse, P. et al. (2011). Effect of annealing on structural, morphological, electrical and optical studies of nickel oxide thin films. J. Surf. Eng. Mater. Adv. Technol., $1(2), 35$.

26. Burstein, E. (1954). Anomalous optical absorption limit in InSb. Phys. Rev., 93(3), 632, https://doi.org/10.1103/PhysRev.93.632.

27. Moss, T. (1954). The interpretation of the properties of indium antimonide. Proc. Phys. Soc. B, 67(10), 775-782, https://doi.org/10.1088/0370-1301/67/10/306.

28. Boschloo, G. \& Hagfeldt, A. (2001). Spectroelectrochemistry of nanostructured NiO. J. Phys. Chem. B, 105, 3039-3044, https://doi.org/10.1021/jp003499s.

29. Makhlouf, S., Abedulrahim, M. \& Kassem, M. (2010). Crystallite size dependent optical properties of nanostructured NiO films. J. Optoelectron. Adv. Mater., 4, 1562.

30. Romero, R. et al. (2010). Synthesis and characterization of nanostructured nickel oxide thin films prepared with chemical spray pyrolysis. Thin Solid Films, 518, 4499-4502, https://doi.org/10.1016/j.tsf.2009.12.016.

31. Forouhi, A. \& Bloomer, I. (1991). Calculation of optical constants, $\mathrm{n}$ and $\mathrm{k}$, in the interband region. In Palik, E. D. (ed). Handbook of optical constants of solids. Maryland: College Park, 151-176.

32. Tan, W. et al. (2006). Fundamental optical properties of materials I. Opt. Prop. Condens. Matter Appl., 6, 1, https://doi.org/10.1002/0470021942.ch1.

33. Lee, M. K. \& Lai, Y. T. (2013). Characterization of transparent conducting p-type nickel oxide films grown by liquid phase deposition on glass. J. Phys. D Appl. Phys., 46, 055109, https://doi.org/10.1088/0022-3727/46/5/055109.

34. Ahmad, S. \& Haq, M. U. (2014). A study of energy gap, refractive index and electronic polarizability of ternary chalcopyrite semiconductors. Iran. J. Phys. Res., 14(3), 89-93.

35. Reddy, R. et al. (2003). Dependence of physical parameters of compound semiconductors on refractive index. Def. Sci. J., 53(3), 239, https://doi.org/ $10.14429 /$ dsj.53.2272. 